\title{
Goal Programming Model for Optimizing The Management of Brackish Water Milkfish Ponds in Gresik
}

\author{
M. Fatkhur Rohman, Moses Laksono Singgih and Udisubakti Ciptomulyono \\ Department of Industrial and Systems Engineering, Institute of Teknologi Sepuluh Nopember, Surabaya \\ e-mail: udisubakti@gmail.com
}

\begin{abstract}
National fish consumption is increasing every year, both sea fish and fish farming. That is because the appeal and invitation of the government to consume fresh fish (white meat) which contains lots of vitamins and protein. Milkfish is one of the most consumed fish species because it is easy to get and the price is relatively cheap. One of the biggest milkfish producers in East Java is located in Gresik Regency. The fulfillment of milkfish consumption needs depends on its productivity. Milkfish productivity depends on the area of the pond. The greater the land area, the more milk fish can be produced. However, milkfish farming is often constrained by the size of ponds, so the amount of milkfish harvest is also limited. In this study, the goal programming method is used to obtain several objectives, namely maximizing profits, minimizing capital, minimizing production costs and inventory costs, taking into account the changing demands in each harvest period, population density, milkfish survival rate and growth rate. The profit from selling the harvest can be optimized by selling some fish (on demand) and re-raising the remaining milk fish from the harvest (inventory) for resale in the next harvest period. Although production costs and inventory costs increase with more food, these benefits will be maximized compared to selling the entire harvest during that period. Because the greater the weight of milk fish, the higher the selling price. So the benefits will be far more leverage.
\end{abstract}

Keywords-Area of The Pond, Demand, Goal Programming, Growth Rate, Milkfish, Population Density, Survival Rate.

\section{I.INTRODUCTION}

$\mathrm{A}$ CCORDING to the Maritime and Fisheries Ministerial Regulation No.29/Permen-KP/2016, fisheries are all activities related to the management of fish resources and the environment, from pre-production, production, processing and marketing carried out in a fisheries business. Whereas fisheries management is all efforts, including integrated processes in information gathering, analysis, planning, consultation, decision making, allocation of fish resources, and implementation and law enforcement of laws and regulations in the field of fisheries, which are carried out by the government or other authorities which is directed towards achieving sustainable productivity of aquatic resources and agreed objectives.

The industrialization of marine and fisheries according to Permen KP No. PER.27/MEN/2012 is the connection between upstream and downstream production systems that are useful to increase the scale and quality of production, productivity, competitiveness, and value added in marine and fisheries resources in a sustainable manner [1].

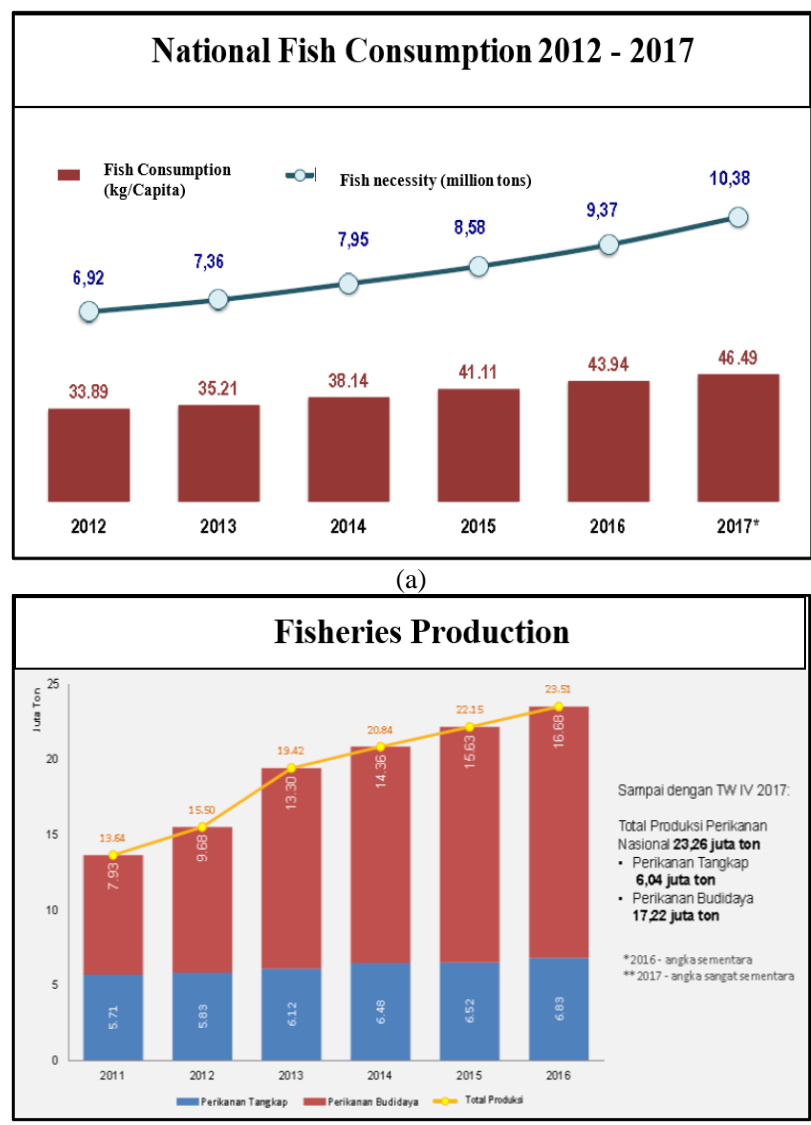

(b)

Figure 1. (a) National Fish Consumption (b) Land and sea fisheries production.

The potential of Indonesian fisheries is huge so that it can provide maximum benefits in a sustainable manner for the country and the community, if managed properly and responsibly. It has also been mandated in Law of the Republic of Indonesia Number 45 of 2009 article 6 paragraph 1 which emphasizes that fisheries management is aimed at achieving optimal and sustainable benefits, and ensuring the preservation of fish resources. However, up to now most of the national fisheries activities have in fact not shown optimal, sustainable performance and guarantee the preservation of fish resources, both in capture fisheries and aquaculture [2].

The need for fish consumption continues to increase along with increasing population growth. On the other hand, fishermen's catch tends to decrease so that the dependence on fish farming is higher. Because of these limitations, the 
The $6^{\text {th }}$ International Seminar on Science and Technology (ISST) 2020

July $25^{\text {th }}, 2020$, Institut Teknologi Sepuluh Nopember, Surabaya, Indonesia

Table 1.

Milkfish Production Regency/city 2015

\begin{tabular}{ccccc}
\hline \hline No & Regency/City & Production (Ton) & Area (Ha) & Productivity (Ton/Ha) \\
\hline 1 & Gresik Regency & 40584 & 17335 & 2,34 \\
2 & Sidoarjo Regency & 33864 & 15548 & 2,18 \\
3 & Surabaya City & 4609 & 4604 & 1 \\
4 & Pasuruan Regency & 4371 & 2510 & 1,74 \\
5 & Tuban Regency & 4291 & 790 & 5,43 \\
\hline \hline
\end{tabular}

Table 2.

Parameter and Variable Decision

\begin{tabular}{cccccc}
\hline \hline & $\mathrm{t}-1$ & $\mathrm{t}-2$ & $\mathrm{t}-3$ & $\mathrm{t}-4$ & $\mathrm{t}-5$ \\
\hline Milkfish 1 (200 gr) & $\mathrm{x} 11$ & $\mathrm{x} 12$ & $\mathrm{x} 13$ & $\mathrm{x} 14$ & $\mathrm{x} 15$ \\
Milkfish 2 (250 gr) & $\mathrm{x} 21$ & $\mathrm{x} 22$ & $\mathrm{x} 23$ & $\mathrm{x} 24$ & $\mathrm{x} 25$ \\
Milkfish 3 (330 gr) & $\mathrm{x} 31$ & $\mathrm{x} 32$ & $\mathrm{x} 33$ & $\mathrm{x} 34$ & $\mathrm{x} 35$ \\
Milkfish 4 (400 gr) & $\mathrm{x} 41$ & $\mathrm{x} 42$ & $\mathrm{x} 53$ & $\mathrm{x} 54$ & $\mathrm{x} 45$ \\
Milkfish 5 (500 gr) & $\mathrm{x} 51$ & 5500 & 5500 & $\mathrm{x} 55$ \\
Capacity & 5500 & 4833 & 4778 & 4770 & 5500 \\
Demand & 4700 & & & 4794 \\
\hline \hline
\end{tabular}

increase in fisheries production is directed at aquaculture activities. Pond cultivation that is widely known by coastal communities is milkfish cultivation. But the culture applied is still traditional (low input so that productivity is also low) so that with a touch of technology and a Good Fish Culture Method (CBIB) is expected to increase productivity [3].

The tendency of consumer interest in fish needs, can be shown in Figure 1 (a). National fish consumption shows an increase every year starting from 2012 with a total consumption of $33.89 \mathrm{~kg} /$ capita until in 2017 reaching the amount of consumption of $46.49 \mathrm{~kg} / \mathrm{capita}$. But the number of fish consumption has not been able to meet the national demand for fish that continues to creep up every year, from 6.92 million tons in 2012 to 2017 reaching 10.38 million tons.

The greatest potential in the agricultural sector is the production or capture of fisheries, and also includes processed products from the fisheries sector. This has also been supported by the many marketing places for processed fishery products in the form of restaurants with a mainstay menu from fish and also shops that sell processed fishery products. Consumers who are interested in processed fishery products consist of many large factory workers, then employees and the local community. In addition, the flow of religious tourists visiting the tombs of Sunan Maulana Malik Ibrahim, and Sunan Giri, makes a very potential culinary market developed in Gresik Regency [4].

In recent years the results of inland or aquaculture production are greater each year when compared to marine or capture fisheries. In Figure 1 (b) explained, that in 2011 marine fisheries production reached 5.71 million tons, while inland fisheries production reached 7.93 million tons. However in 2016, marine fisheries production only reached 6.83 million tons, while production inland fisheries far left sea fisheries production which reached 16.68 million tons [5]. The fisheries sector plays an important role in shaping national GDP with the main focus being the capture fisheries and aquaculture sectors. The Director General of Aquaculture said that milkfish is one of the products of choice to increase aquaculture production at an affordable price, rich in nutritional content, an easy cultivation process, and can help increase the income of coastal communitie [6]

Milkfish is a native sea water fish known as an adventurer, and is able to live in brackish water, and even can live in fresh water. The cultivation of milk fish in Indonesia has developed very rapidly, due to the increasing market demand. Milkfish can be cultivated in sea water, brackish water, and fresh water. The cultivation of milkfish is carried out to meet the needs of fish consumption, both nationally and internationally and also as bait in the process of catching sea fish.

The business opportunity for milkfish cultivation in East Java is quite large and milkfish production is spread in several cities and regencies. Table 1, areas with the largest milkfish production include Gresik Regency, Sidoarjo Regency, Pasuruan Regency, Surabaya City, and Tuban Regency. Gresik Regency is the biggest milkfish producing center in East Java.

Besides having an important role in the economic sector, milkfish also has a meaning of identity and tradition for the residents of Gresik. The local government of Gresik Regency also holds a traditional milkfish contest and milkfish market festival every year on the 27th of Ramadan, with the aim of preserving the tradition that has been carried out for years and is also a form of appreciation from the government of Gresik Regency to farmers in their ponds for their efforts in developing and milkfish cultivation.

But along with the continued development of aquaculture and increasing sales of milk fish in Gresik district, farmers often complain about the lack of income from milkfish pond business. These constraints are often felt by pond farmers during the harvest period. The minimal amount of milkfish cannot cover capital costs and feed costs, so farmers often suffer losses. If the loss is often experienced by farmers, it does not rule out the possibility of interest in raising milkfish that will decrease, so that it can reduce the productivity of milk fish in Gresik Regency.

The main factor that farmers complained about was that the land for milkfish ponds owned or rented was not large enough 


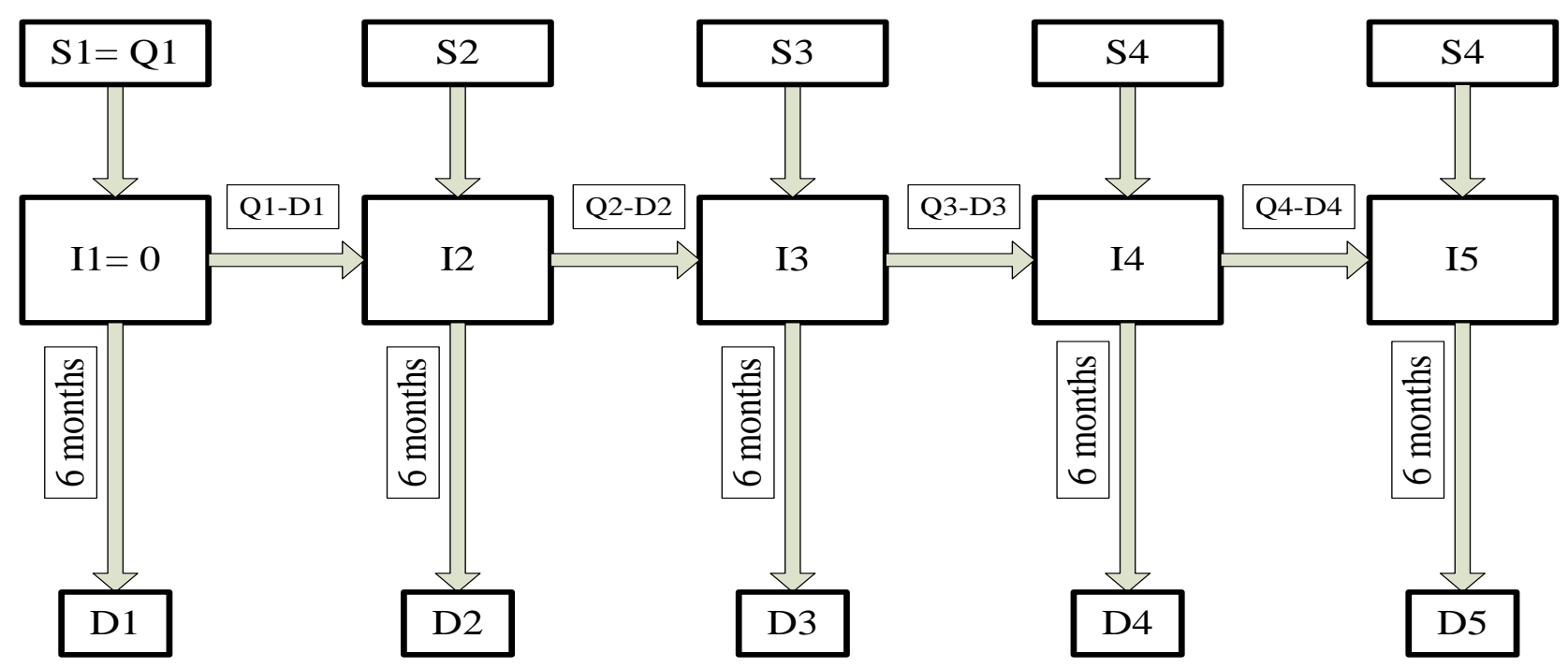

Figure 2. Variable of Research.

to produce more milk fish. The limitation of milkfish ponds must be better utilized to produce a large amount of milkfish, but must pay attention to population density growth rate and survival rate.

Research on milkfish has been carried out by many academics and researchers, both from the private sector or from the ministry of maritime affairs and fisheries. However, the majority of these studies use statistical methods that lead to the formulation of strategies, such as the development of the milkfish market development strategy, competitiveness analysis, formulation of policy strategies, analysis of factors affecting farmers' income, and others. However, it is very rare for technical research to determine the best way and steps in milkfish production.

In this study, goal programming is used to complete several objectives, namely maximizing revenue, minimizing production and inventory costs, minimizing capital. So the title of this research is "Goal Programming Model for Optimizing the Management of Brackish Water Milkfish Ponds in Gresik".

\section{GOAL PROGRAMMING}

Goal programming can be used to satisfy decision-maker desires. What is needed is to determine and prioritize objectives and also state the relationship between decision variables and goals with linear functions. The desicion-maker must also provide the sequence number of the ranking of goals, so that the goal programming model can minimize the deviation from the main objectives and the constraints that have been determined [7]. Goal programming has become and remains a widely used technique for solving multiplecriteria decision problems and multiple-objective decision problems by finding a satisfying set of solutions [8].

Goal Programming is a modification or special variation of linear programming that has many goals to be achieved. Goal Programming aims to minimize some deviations from certain goals by considering a hierarchy of priorities. The difference in goal programming and linear programming only lies in a pair of deviational variables that will appear in the objective function and constraint functions. Deviational variables function to accommodate deviations or deviations that will occur in the value of the left segment of an equation constraint to the value of the right segment. In order for the deviation to be minimum, meaning that the value of the left-hand side of a constraint equation "as much as possible" approaches the value of the right-hand side, then the deviation variable must be minimized in the objective function [9].

The goal programming model is widely applied in several decision-making situations, such as finance, production, marketing, and accounting. This research focuses on the production stage (enlargement) that can determine the profitability of a brackish water milkfish pond business. This research was conducted in Karangrejo Village, Kec. Manyar, Kab. Gresik which coincides in a brackish-water milkfish pond with an area of $1 \mathrm{Ha}(10,000 \mathrm{~m} 2)$. Farmers want maximum production results with a large profit from the pond. While the milkfish harvest can only be done starting in the sixth month.

\section{A. Survival Rate, Growth rate and Population Density}

Survival rate is the survival rate of a type of fish in the cultivation process that starts from the process of spreading fish seeds to the harvesting process. The formula used to calculate survival rate (SR) is as follows [10]:

$S R=\frac{N t}{N o} X 100 \%$

Where:

$\mathrm{Nt}=$ number of fish harvested (tail)

No $\quad=$ number of fish stocked (tail)

Growth rate is the rate of growth of fish expressed as a change in the average weight of fish during the cultivation process. The formula used to calculate growth rate (GR) is as follows [10]:

$G R=\frac{\ln W t-\ln W o}{t} X 100 \%$

Where:

$\mathrm{Wt} \quad=$ weight of harvested fish $(\mathrm{gr})$

Wo = weight of fish stocked (gr)

$\mathrm{t}=$ cultivation process time (days) 
The $6^{\text {th }}$ International Seminar on Science and Technology (ISST) 2020

July $25^{\text {th }}, 2020$, Institut Teknologi Sepuluh Nopember, Surabaya, Indonesia

Table 3.

Software Calculation Result

\begin{tabular}{ccc}
\hline \hline No & Goal & Parameter Value \\
1 & Objective function value & 77.873 .320 \\
Maximize Revenue & 0 \\
2 & Minimize Production Cost and Inventory Cost & $\mathrm{D} 12 \mathrm{P}=56.918 .960$ \\
3 & Minimize Capital & $\mathrm{D} 13 \mathrm{P}=20.954 .360$ \\
4 & $\mathrm{x} 11$ & 4700 \\
5 & $\mathrm{x} 12$ & 3975 \\
6 & $\mathrm{x} 13$ & 3847 \\
7 & $\mathrm{x} 14$ & 3828 \\
8 & $\mathrm{x} 15$ & 3884 \\
9 & $\mathrm{x} 22$ & 858 \\
10 & $\mathrm{x} 23$ & 931 \\
11 & $\mathrm{x} 24$ & 942 \\
& $\mathrm{x} 25$ & 910 \\
\hline \hline
\end{tabular}

Population density in a pond can determine the level of intensity of maintenance. The higher population density means the more amount of fish biomass per unit area, the higher the level of maintenance. High population density will have an impact on the amount of oxygen and feed requirements as well as metabolic waste such as feces, amoniac, and carbon dioxide, so that it can inhibit the rate of fish growth [10]

\section{B. Mathematic Model}

Index is an important term contained in a book or paper that has certain information that is related in a modeling and is useful for easy reading mathematical models. The index of this research is as follows:

$\mathrm{n}=$ index of the type of milkfish produced $(\mathrm{n}=1,2, \ldots, \mathrm{N})$

$\mathrm{t}=$ harvest period index $(\mathrm{t}=1,2, \ldots, \mathrm{T})$

Decision variables are variables that affect the value of the desired goals and the values to be sought. In this study there are 1 ponds with an area of $10,000 \mathrm{~m} 2(1 \mathrm{Ha})$. The pond is filled with milkfish seeds with the number of 1 rean $(5500$ individuals). The desired time to harvest the pond results begins in the 6th month until the next period. The variables defined in this study will be explained in Table 2 and Figure 2.

From Table 2 and Figure 2, decision variables can be determined to make it easier to understand mathematical models in the modeling that will be carried out. The decision variables that have been determined in this study are:

$X_{n t} \quad=$ number of milkfish produced in the period $\mathrm{t}$ (tail)

$X_{n t} \quad=S_{n t}+I_{n t-1}$

$S_{n t} \quad=$ Number of milkfish purchased in period $\mathrm{t}$ (tail)

$I_{n t-1}=$ Number of remaining milkfish of period t-1 (tail)

The parameter is a predetermined value and can be implemented in a calculation. The parameters set in this study are as follows:

$D_{n t}=$ Demand for milkfish $\mathrm{n}$ in the harvest period $\mathrm{t}$ (tail)

$K_{t} \quad=$ milkfish capacity in each period $\mathrm{t}$ (tail)

$P_{n t}=$ Amount of milkfish feed in the period $\mathrm{t}(\mathrm{kg})$

$p_{n t}=$ Need for milkfish feed in the period $\mathrm{t}(\mathrm{kg} / \mathrm{tail})$

$H_{n t}=$ Selling price of milkfish $\mathrm{n}$ harvested in period $\mathrm{t}$ (Rp/fish)

$K P=$ Population density $($ tail $/ \mathrm{m} 2)$

$S R=$ Survival rate $(\%)$

$G R=$ Growth rate $(\mathrm{gr} / \mathrm{hari})$

Fixed Cost and Variable Cost: $b m_{t}=$ Rent of machine capital (water pump) for period $\mathrm{t}$ (Rp/month)

$b s_{t}=$ Rent of pond capital for period $\mathrm{t}(\mathrm{Rp} / \mathrm{month})$

$b b_{t}=$ Cost of milkfish seedlings in the period $\mathrm{t}(\mathrm{Rp} / \mathrm{head})$

$b p_{n t}=$ Cost of milkfish feed in the period $\mathrm{t}(\mathrm{Rp} / \mathrm{kg})$

$b o_{t}=$ Operating costs in the period $\mathrm{t}(\mathrm{Rp} / \mathrm{month})$

$b t_{t}=$ Labor costs in period $\mathrm{t}(\mathrm{Rp})$

\section{Objective Function and Constraint}

Farmers want to know more about which milkfish pond production process can provide the maximum benefit with the lowest possible production, inventory and capital costs. The objective function in modeling goal programming is to minimize negative deviations. The objective function in this research is:

$a=\sum_{i} P\left(d_{i}^{-}-d_{i}^{+}\right)$

Min $=P_{1} d_{1}^{-}+P_{2} d_{2}^{+}+P_{3} d_{3}^{+}$

The constraints set in this programming need to be done and must be met (must not be violated). The limits set are as follows:

\section{1) Maximize revenue}

Large revenue from sales is a target that must be met. The sale of milkfish depends on the amount of milkfish produced during this period. In addition, the larger the size of the milk fish sold, the higher the selling price. Mathematically, the constraints of income goals are:

$\sum_{n=1}^{N} \sum_{t=1}^{T} H_{n t}\left(X_{n t}\right)+d_{i}^{-}-d_{i}^{+}=$max revenue

The minimized deviation variable is $d_{1}^{-}$.

\section{2) Minimize production costs and inventory costs}

Production costs are costs during the process of raising milk fish in a pond. The more milkfish that are cultivated, the greater the cost of production. While inventory costs are costs incurred for storing the remaining milkfish sales. The milk fish is kept alive and still in the process of enlarging, so that the production costs are the same as the inventory costs. The remaining milkfish from the sale of the previous period requires more feed to meet the needs of the weft feed. If the feed needs are not met, the growth of milkfish will stop and even death will occur. Production costs in milkfish enlargement include operational costs, labor costs and milk fish feed costs. Mathematically, the goal constraints of production costs and inventory costs are: 
The $6^{\text {th }}$ International Seminar on Science and Technology (ISST) 2020

July $25^{\text {th }}$, 2020, Institut Teknologi Sepuluh Nopember, Surabaya, Indonesia

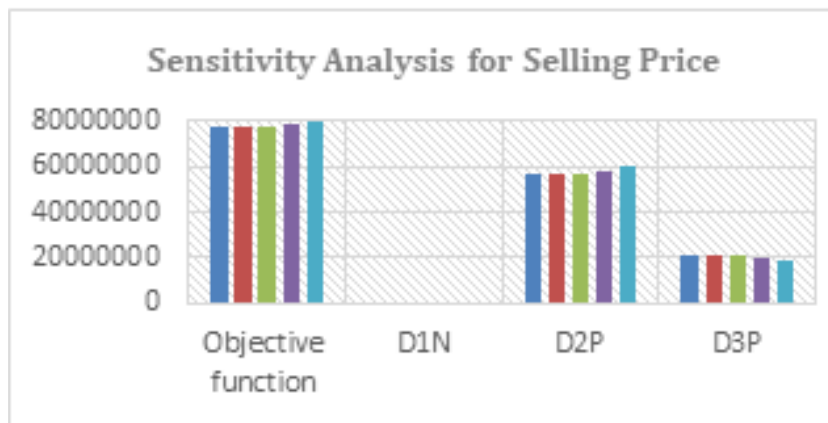

- Awal naik $15 \%$ naik $30 \%$ - Turun $15 \%$ - Turun $30 \%$

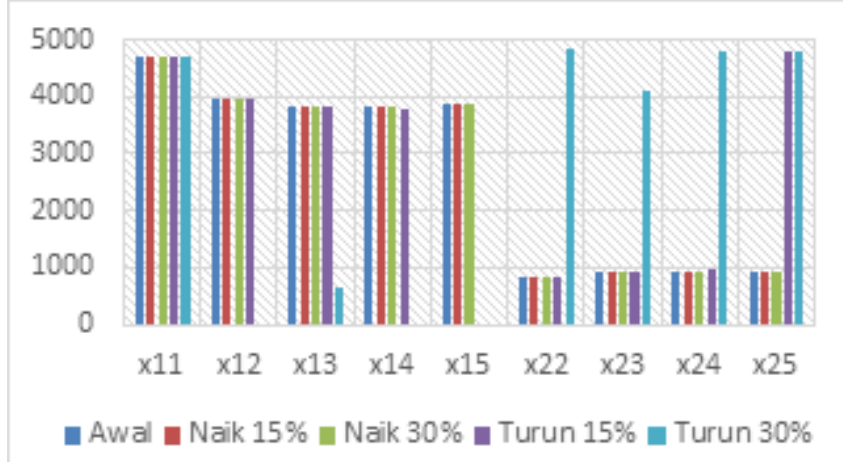

(a)
Sensitivity Analysis for Demand

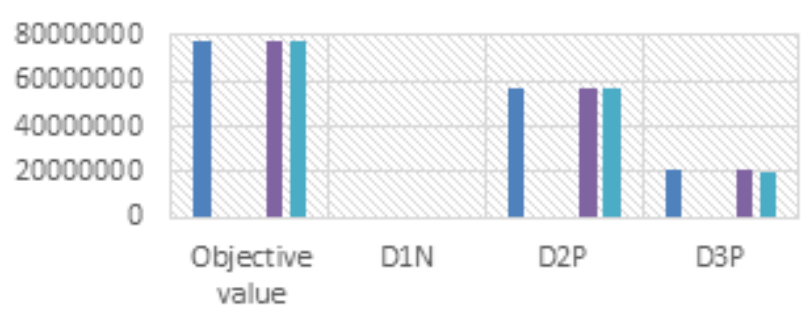

- Awal naik $5 \%$ naik $10 \%$-Turun $5 \%$ - Turun $10 \%$

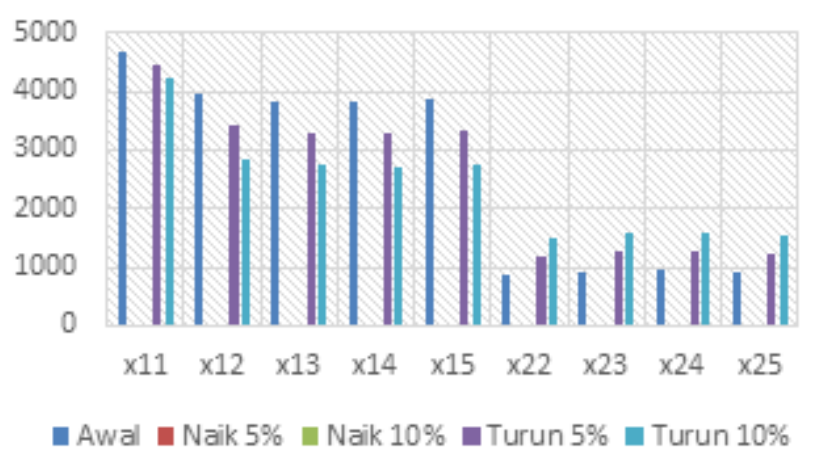

(b)

Figure 3. (a) Sensitivity Analysis for Selling Price, (b) Sensitivity Analysiss for Demand.

$\sum_{n=1}^{N} \sum_{t=1}^{T}\left(b p_{n t} * X_{n t}\right)+b o_{t}+b t_{t}+d_{i}^{-}-d_{i}^{+}=0$

The minimized deviation variable is $d_{2}^{+}$.

\section{3) Minimize capital}

Capital is a minimized factor to get maximum profit. In this study, capital consists of purchasing milk fish seeds, diesel engine rental and pond rental. Mathematically, the constraints of capital objectives are:

$\sum_{n=1}^{N} \sum_{t=1}^{T}\left(b b_{t} * X_{n t}\right)+b m_{t}+b s_{t}+d_{i}^{-}-d_{i}^{+}=0$

The minimized deviation variable is $d_{3}^{+}$.

\section{4) Demand}

The demand for milkfish needed by the market at each harvest period must be fulfilled and must not be less than the amount of demand demanded, because it can help in optimizing income. Mathematically, the demand constraint function is:

$\sum_{n=1}^{N} \sum_{t=1}^{T} X_{n t} \geq D_{t}$

\section{5) Maximizing pond capacity}

Pond capacity is the main key in the cultivation of weirs because it affects the development of milkfish. Pond capacity must be controlled so that the dam fish get maximum space. So that the amount of milk fish in a pond must not exceed the specified capacity limit. Mathematically, the pond capacity constraint function is:

$\sum_{n=1}^{N} \sum_{t=1}^{T} X_{n t} \leq 5500 *$ Survival Rate

\section{6) Feed requirements}

Feed needs in each period must be met and must not be less. So that the growth of milk fish is not hampered and there is no death. Mathematically, the function constraints of feed requirements are:

$\sum_{n=1}^{N} \sum_{t=1}^{T} X_{n t} * p_{n t} \geq P_{n t} \times$ Growth Rate

\section{RESULT AND DISCUSSION}

The optimal solution from the software calculation results is an objective function value of $77.508,420$ with 14 iterations. The types of fish that are feasible and are recommended for harvest are fish species 1 and 2 with an average weight of each fish of 200 grams and 250 grams (x11, $\mathrm{x} 12, \mathrm{x} 13, \mathrm{x} 14, \mathrm{x} 15, \mathrm{x} 22, \mathrm{x} 23, \mathrm{x} 24, \mathrm{x} 25)$. Two types of fish that can be harvested at five different periods do not significantly affect the cost of production and inventory costs, because they are not burdened in feeding. The longer and the bigger the milk fish that are in the pond, the need for feed will increase, and the velocity of money will stop and be restrained. The results of software calculations for other objectives set in this study will be explained in Table 3 .

\section{A. Sensitivity Analysis}

Sensitivity analysis is an analysis conducted to determine the impact that occurs in the performance of a system due to changes in parameters in generating a profit. Sensitivity analysis is also used to find out how sensitive a decision is, in the end the sensitivity analysis will give an idea of the extent to which a decision will be strong enough against the parameters that are changed (Pujawan, 1995) [11].

The selling price of milkfish always changes depending on the harvest season. During the rainy season, the price of milk fish will be cheaper because the water needs are very fulfilled so that many farmers raise milk fish in ponds and ponds. Conversely, if the dry season, water needs will be reduced so 
The $6^{\text {th }}$ International Seminar on Science and Technology (ISST) 2020

July $25^{\text {th }}$, 2020, Institut Teknologi Sepuluh Nopember, Surabaya, Indonesia

Sensitivity Analysis for Production Costs

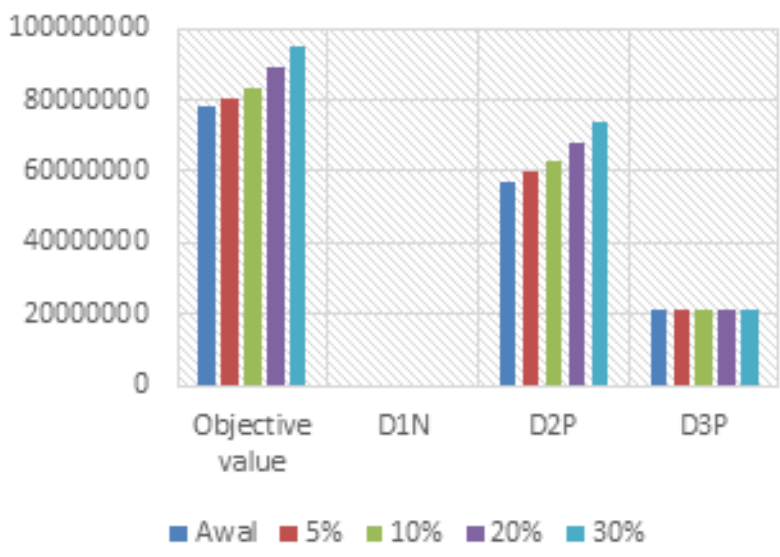

Sensitivity Analysis for Capital Value

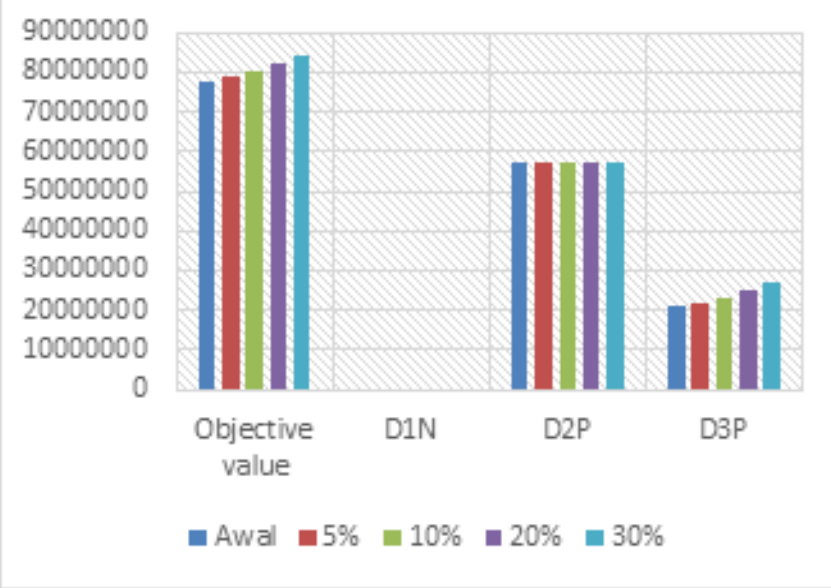

(b)

Figure 4. (a) Sensitivity Analysis for Production Costs, (b) Sensitivity Analysiss for Capital Value.

that only a small proportion of farmers raise milkfish. Figure 3 (a) will explain the changes in the increase and decrease in prices of milk fish selling prices that can affect the optimal solution. Assuming the costs of production, capital and demand are of fixed value (unchanged). The sensitivity analysis in Figure 3 (a) explained that when the selling price of milkfish increased by $15 \%$ and $30 \%$ from the normal selling price, it did not affect the objective function value and other values. But when the selling price of milkfish decreases by $15 \%$ and $30 \%$, the objective function value and the amount of milkfish harvest change in each period. At the $15 \%$ decline in the selling price of milk fish, the objective function value changes to 78292050 . The harvest process of the milkfish changes to 3799 tails and x24 to 971 tails. Whereas for the process of harvesting the milkfish $\times 15$ changed to 0 and $\times 24$ became 4794 tails. When the selling price of milkfish decreases by $30 \%$, the objective function value changes to 79464870. The process of harvesting milkfish x12, x14 and $\mathrm{x} 15$ changes to zero. The process of harvesting milkfish x13 changed to 661 tails. As for the process of harvesting milkfish x22, x23, x24 and x25 changed to 4833, 4116, 4770 and 4794 tails.

Production costs have the potential to always increase over time. Milkfish food is the most frequently experienced price increase, even the price change occurs very briefly and has increased again. As for labor, the price increase depends on the policy of the milkfish pond business owner. Figure 4 (a) will explain changes in production cost increases that can affect optimal solutions. Assuming the sale price, capital and demand are still fixed (unchanged). The sensitivity analysis in Figure 4 (a) explains that when the production costs for milkfish farming increase from the normal production costs, the value of the objective function changes. But the amount of milkfish harvest remains the same as the initial value and does not change in each harvest period. At the level of milkfish production cost increase of 5\%, the value of the objective function changes to 80722870 . At the level of milkfish production cost increase of $10 \%$, the objective function value changes to 83576060 . At the level of milkfish production cost increase of $20 \%$, the value of the objective function changed to 89258570. At the level of milkfish production cost increase of $30 \%$, the objective function value changed to 94957670.

Capital always increases with time. The milkfish seeds are the most frequent price changes, even the price changes are very short and have increased again. As for the rental of ponds and rental machines, it depends on the policy of the owner of the pond and the machine. Figure 4 (b) will explain changes in capital value increases that can affect optimal solutions. Assuming selling prices, production costs and demand are still fixed (unchanged). The sensitivity analysis in Figure 4 (b) explains that when the capital for milkfish cultivation increases from the normal capital value, the value of the objective function changes. But the amount of milkfish harvest remains the same as the initial value and does not change in each harvest period. At the level of milkfish production cost increase of 5\%, the value of the objective function changes to 78914970. At the level of milkfish production cost increase of $10 \%$, the objective function value changes to 79976850 . At the level of milkfish production cost increase of $20 \%$, the value of the objective function changed to 82060150 . At the level of milkfish production cost increase of $30 \%$, the objective function value changed to 84163680 .

The demand for each period is not always the same and will change over time. When approaching holidays and cultural events, the demand for milkfish will increase. Milkfish demand will decrease when it has entered the rainy season, where water needs for all milkfish ponds can be fulfilled. Figure 3 (b) will explain changes in demand that can affect optimal solutions. Assuming the selling price, production costs and capital value are still fixed (unchanged). The sensitivity analysis in Figure 3 (b) explains that when demand increases by $5 \%$ and $10 \%$ of the initial demand, the optimal value of the solution is not found (no feasible solution found). However, when the demand for each period decreases by $5 \%$ and $10 \%$ of the initial demand, the value of the objective function and the amount of milkfish harvest change in each period. At the level of milkfish demand reduction by $5 \%$, the objective function value changes to 77435490 . The process of harvesting milkfish $\mathrm{x} 11, \mathrm{x} 12, \mathrm{x} 13$, x14 and x15 changes to $4465,3411,3289,3271$ and 3324 tails. As for the process of harvesting milkfish $\times 22, \times 23, \times 24$ and $\times 25$ changed 
to $1180,1250,1260$ and 1230 tails. At the level of decline in milkfish demand by $10 \%$, the objective function value changes to 7699867 . The process of harvesting milkfish $\times 11$, $\mathrm{x} 12, \mathrm{x} 13, \mathrm{x} 14$ and $\mathrm{x} 15$ changes to $4230,2848,2732,2715$ and 2767 tails. As for the process of harvesting milkfish x22, x23, x24 and x25 changed to $1502,1568,1578$ and 1548 tails.

\section{B. Discussion}

Sensitivity analysis on changes in milkfish selling price, production costs for milkfish enlargement, capital needed for milkfish farming and the amount of fish needed to meet market demand has been carried out. The most optimal value that has been obtained from calculations using goal programming software, remains at the initial value that has been used as a parameter in this study.

Optimal value is obtained when the selling price of milkfish does not decrease. However, if the selling price of milkfish decreases, the amount of milkfish harvest for each period is uneven. So it will have an impact on rising production costs. When the production costs for milkfish farming increase in value, the number of harvests of milkfish for each period remains the same as the initial parameters set in this study. However, production costs will change in value. When the capital for milkfish farming increases in value, the amount of harvest for milkfish for each period remains the same as the initial parameters set in this study. But the value of capital will change in value. When market demand increases, the objective function value is not found in software calculations. Meanwhile, when market demand has decreased in number, the objective function value in software calculations can be obtained, but the amount of harvest for each period there is a significant difference with the parameters set in this study.

In general, fish farmers harvest all of the milkfish in the harvest period. For example, when a farmer spreads the seeds of milkfish (nener) for the cultivation process in one pond, then six months later all of the milkfish products will be harvested. This is done to meet the velocity of money so that the sale of milkfish in the harvest period can be used to meet daily needs and to process and replenish ponds with new milkfish seeds.

The results of this study obtained an optimal value when the amount of milk fish harvested is only to meet market demand without having to sell as a whole. The amount of milk fish left over from the sale is still re-raised in the pond to supplement market demand in the next harvest period. Although the production cost (enlargement) of the remaining milkfish from the previous period's sales has increased due to the increasing number of feed needs, but the selling price of the remaining milkfish will increase. This increase in selling price will be more profitable for fish farmers than the whole milk fish harvest sold in one period.

\section{CONCLUSION}

The results of the study with the agreement of the problem at the study site in Karangrejo Village, Kec. Manyar, Kab. Gresik with a pond area of 1 hectare and brackish water milkfish species and are considered to contain salt content, growth rate and a constant survival rate, an optimal compilation value of the amount of milk fish harvested is only for market needs. The amount of milkfish left over from the sale is still re-bred back to the pond to supplement market demand in the next harvest period.

The harvesting process carried out in accordance with the optimal results of the mathematical model in this study is the harvesting process in the 1 st to 5 th period with the types of fish that can be harvested are fish species with an average value of $200 \mathrm{gr} / \mathrm{head}$ and $250 \mathrm{gr} / \mathrm{head}$.

The advice given so that further research can be better is the weight of each milkfish to meet the demand must be more specific. Survival rates and growth rates for each harvest period are not assumed to be linear and constant. The possibility of survival and growth rates for each harvest period can change. Using Dynamic Goal Programming so that future research is more specific and detailed.

\section{REFERENCES}

[1] Bappenas (2016), Kajian Strategi Industrialisasi Perikanan Untuk Mendukung Pembangunan Ekonomi Wilayah, Bappenas, Jakarta.

[2] Bappenas Direktorat Kelautan dan Perikanan (2014), Kajian Strategi Pengelolaan Perikanan Berkelanjutan, Bappenas, Jakarta

[3] Muntalim dan Mas'ud (2014), "Pengembangan Budidaya Dan Teknologi Pengolahan Ikan Bandeng (Chanos - Chanos Forsskal) Di Kabupaten Lamongan Guna Meningkatkan Nilai Tambah", Jurnal Eksakta, Vol.2, No.1.

[4] Bappeda Kabupaten Gresik (2017), Agribis Perikanan Berbasis Industri dan Wisata Religi: Kajian Penentuan Zonasi Ekonomi Sosial Budaya Dalam Mendukung SIDa Kabupaten Gresik, Bappeda, Gresik.

[5] Kementrian Kelautan dan Perikanan (2018), Produktivitas Perikanan Indonesia, KKP, Jakarta.

[6] Dhelia, A. Oktaviani, R. dan Iskandar, B.H. (2018), "Strategi Peningkatan Daya Saing Industri Bandeng Di Kabupaten Indramayu", Jurnal Ekonomi dan Kebijakan Publik, Vol.09, No.1, hal.1-14.

[7] Cristobal, Jose Ramon San (2012), "A Goal Programming Model For Environmental Policy Analysis: Application To Spain”, Elsevier Energy Policy, hal. 303-307.

[8] Chang, Ching-Ter (2011), "Multi-Choice Goal Programming With Utility Function", European Journal of Operational Research, hal. 439-445.

[9] Yuliani, S. dan Pujianta, A. (2014), "Media Pembelajaran Goal Programming Berbasis Multimedia", Jurnal Sarjana Teknik Informatika, Vol.2, No.1

[10] Faisyal, Y. dan Widowati, L. (2016), "Pengaruh Padat Tebar Terhadap Pertumbuhan dan Kelulushidupan Ikan Bandeng (Chanos Chanos) di Kermba Jaring Apung di Perairan Terabrasi Desa Kaliwlingi Kabupaten Brebes", Journal of Aquaculture Management and Technology, Vol.5, No.1, Hal.155-161.

[11] Pujawan, I.N. (1995), Ekonomi Teknik, Edisi Kedua, Guna Widya, Surabaya, Indonesia. 